\title{
Induction of Puberty in Red Spotted Grouper, Epinephelus akaara By Water Temperature
}

Sueng-Bo Oh, Chi- Hoon Lee and Young-Don Lee*

Marine Science Institute, Jeju National University, Jeju, South Korea

\begin{abstract}
It takes quite a long time for the grouper to spawn. In the case of red spotted grouper (Epinephelus akaara), at least three to four years of rearing is usually required to reproduce them for the first time. Reproductive control techniques can be applied to repress, delay or advance the onset of puberty. Thus, they can be used to accelerate the process of selective breeding in this species. The present study investigated whether alterations of rearing water temperature (WT) can advance the onset of puberty in the red spotted grouper. Juvenile red spotted grouper (110 $\mathrm{DAH}, 7.25 \pm 0.5 \mathrm{~cm}, 6.45 \pm 1.5 \mathrm{~g}$ ) were randomly divided into 4 groups and reared for approximately 10 months (from Nov. 2014 to Aug. 2015) at four different WT: natural condition $\left(12.6-19.5^{\circ} \mathrm{C}\right), 20 \pm 0.5^{\circ} \mathrm{C}, 24 \pm 0.5^{\circ} \mathrm{C}$ and 28 $\pm 0.5^{\circ} \mathrm{C}$ treatment. When they were reared at $24 \pm 0.5^{\circ} \mathrm{C}$ or $28 \pm 0.5^{\circ} \mathrm{C} \mathrm{WT}$, sexually mature individuals appeared within 12 months after hatching during their breeding season (Jul. to Aug.). The mRNA levels of reproduction-related genes such as Kisspeptin, $\mathrm{GnRH}, \mathrm{FSH} \beta$ and $\mathrm{LH} \beta$ were higher in the $24 \pm 0.5^{\circ} \mathrm{C}$ and $28 \pm 0.5^{\circ} \mathrm{C}$ treatment group than the other groups $(\mathrm{P}<0.05)$. Mature yolk stage oocytes $(\geq 300 \mu \mathrm{m}$ diameter) were found in the ovaries of female red spotted grouper reared at $24 \pm 0.5^{\circ} \mathrm{C}$ or $28 \pm 0.5^{\circ} \mathrm{C}$ groups, while only oogonia were found at natural condition and peri-nucleolus stage oocytes were observed at $20 \pm 0.5^{\circ} \mathrm{C}$ group, respectively. The one-year-old mature females ovulated $6-10 \mathrm{ml}$ of eggs that corresponded to $10 \%$ of their body weight. In artificial fertilization performed at $24 \pm$ $0.5^{\circ} \mathrm{C} \mathrm{WT}$, the fertilization and hatching rates were determined to be $95 \%$ and $97 \%$, respectively. This is the first report demonstrating that rearing at 24 or $28^{\circ} \mathrm{C}$ WT can significantly advance the onset of puberty in the red spotted grouper.
\end{abstract}

Keywords: Puberty; Red spotted grouper; Epinephelus akaara; Water temperature.

\section{Introduction}

The puberty of fish is the period when the capacity to reproduce gain for the first time in their lives after sexual differentiation $[1,2]$, which makes the control of puberty critically important in aquaculture industry [3]. The puberty of fish is mainly associated with the activities of the brain-pituitary-gonad axis (B-P-G axis) with the age and somatic growth $[4,5]$. In fish, the process of gametogenesis is activated or repressed by physiological factors and environmental factors. The most common physiological factors are nutrition, stress, and immunity; while the environmental factors include light, water temperature, water pressure, and tide.

Light and water temperature are the representative environmental factors involved in fish gametogenesis, playing an especially crucial role in the puberty of various farmed fish species including Atlantic cod [6]. Apart from the species whose onset of puberty is mainly influenced by the photoperiod, such as Eurasian perch and yellow perch $[7,8]$, there are fish species whose puberty is most essentially influenced by water temperature, including Atlantic halibut (6 to $9^{\circ} \mathrm{C}$ ) and grass carp $\left(24^{\circ} \mathrm{C}\right)$ $[9,10]$.

Such environmental factors stimulate the receptors in each organ and are summed up in the brain that lead to the activation of B-P-G axis. Previous studies on the puberty and sex maturation of seabream [11] and longtooth grouper [12] mostly focused on the activities of Gonadotropin-Releasing Hormones (GnRH) and Gonadotropic Hormones (GtHs). However, recent studies in fish (mackerels) have reported Kisspeptine (Kiss) and its receptor, G-protein receptor54 (GPR54), as the upstream factors that facilitate the secretion of GnRH [13]. There has been a recent investigation on the roles played by Kiss and Gpr54 in sex maturation during blacktip grouper [14].

Most grouper species inhabit subtropical and tropical regions. The red spotted grouper (Epinephelus akaara) is found in China, Korea and southern Japan. Spawning period of E. akaara that inhabits the coasts of Jeju Island in Korea is between July and August (summer breeder). The sex characteristic of red spotted grouper is a protogynous hermaphrodite and sex maturation occur three years after sexual differentiation into female, some of which (longer than $26 \mathrm{~cm}$; over 5-year-old) reverses the sex to male [15-18]. The red spotted grouper is commercially important species in Asia, but it is currently classified as an endangered species by the Food and Agriculture Organization (FAO) and the International Union for Conservation of Nature [19,20].

Thus, this study, we induced puberty of red spotted grouper that require a long period of time to reach puberty, by controlling the rearing water temperature. During inducing puberty, the study also comparatively analyzed the gonad development and the expression patterns of Kiss, Gpr54, GnRH, and GtHs, which are essential in exploring the expression mechanisms of reproduction-related genes during puberty.

\section{Materials and Methods}

\section{Experimental fish and breeding management}

Juvenile red spotted grouper (110 days after hatching; $7.25 \pm 0.5$ $\mathrm{cm} ; 6.45 \pm 1.5 \mathrm{~g}$ ) seed-produced at the Marine Science Institute of Jeju

*Corresponding author: Young-Don Lee, Marine Science Institute, Jeju National University, Jeju 63333, South Korea, Tel: +82-64-783-8281; Fax: +82 64-782-8281; E-mail: leemri@jejunu.ac.kr

Received May 22, 2018; Accepted June 12, 2018; Published June 15, 2018

Citation: Oh SB, Lee CH, Lee YD (2018) Induction of Puberty in Red Spotted Grouper, Epinephelus akaara By Water Temperature. J Aquac Res Development 9: 537. doi: 10.4172/2155-9546.1000537

Copyright: (c) 2018 Oh SB, et al. This is an open-access article distributed under the terms of the Creative Commons Attribution License, which permits unrestricted use, distribution, and reproduction in any medium, provided the original author and source are credited. 
Citation: Oh SB, Lee CH, Lee YD (2018) Induction of Puberty in Red Spotted Grouper, Epinephelus akaara By Water Temperature. J Aquac Res Development 9: 537. doi: 10.4172/2155-9546.1000537

Page 2 of 7

National University was used as the experimental fish. The juvenile red spotted grouper used in the experiments had been seed-produced in July 2014, under the condition of 14L:10D photoperiod and $21.0 \pm$ $1.0^{\circ} \mathrm{C}$ rearing WT control, from the adult red spotted grouper reared at the Marine Science Institute. For the induction of puberty in red spotted grouper through the rearing WT control, two experimental plots were devised: the natural condition WT (NC) and the $20 \pm 0.5^{\circ} \mathrm{C}$, $24 \pm 0.5^{\circ} \mathrm{C}$, and $28 \pm 0.5^{\circ} \mathrm{C}$ treatment groups, each group containing 600 fish. The water temperature was controlled using a heat pump. Six tone water tanks $(3 \mathrm{~m} \times 85 \mathrm{~cm})$ was used for rearing the fish based on running water culture, with the circulating flow rate at each tank being $15-17 \mathrm{~L} / \mathrm{min}$. The experimental duration lasted approx. 8 months from October 2014 to July 2015. The photoperiod during this time was treated as equivalent to the period of natural light. Other conditions were dissolved oxygen (DO) $8 \pm 1 \mathrm{mg} / \mathrm{L}$; salinity $30 \pm 2 \mathrm{ppt}$; pH $8.0 \pm$ 0.1 ; feed was provided twice a day.

\section{Dissection and histological examination of the experimental fish}

To examine the activities of B-P-G axis and the steps of gonad development, the red spotted grouper was randomly selected by $10-15$ fish from each tank during their spawning period in July. The length and weight of the fish were measured after they were anesthetized using $0.01 \%$ 2-penoxyethanol, and the grouper were stored at $-80^{\circ} \mathrm{C}$ before removing the brain including the pituitary gland for analysis. To compare the gonadosomatic index (GSI) and gonad development between the experimental groups, the gonads of the experimental fish were removed, weighed, and fixed using Bouin's solution for histological analysis. The tissue samples were cut to 5-7 $\mu \mathrm{m}$ thickness using the commonly used paraffin sectioning method, then they were counterstained using Hematoxylin and $0.5 \%$ Eosin, after which a light microscope (Olympus BX53, Japan) was used for inspection.

\section{Total RNA extraction and cDNA synthesis}

For total RNA extraction, the brain and gonad tissues obtained from the fish of each experimental group were placed in a $1.7 \mathrm{ml}$ tube with $600 \mu \mathrm{L}$ RiboEx ${ }^{\mathrm{TM}} \mathrm{LS}$ (GeneAll, Korea) and homogenized using a homogenizer. Into the tube containing the homogenized tissues, $0.2 \mu \mathrm{L}$ chloroform per 1.0 $\mu \mathrm{L}$ RiboEx ${ }^{\mathrm{TM}}$ LS was added, and the reaction was left at room temperature for $5 \mathrm{~min}$. Next, using a centrifuge (Vision VS-15000CFN) maintained at $4^{\circ} \mathrm{C}$, the total RNA was isolated by centrifugation at $12,000 \mathrm{x}$ g for $15 \mathrm{~min}$, after which the supernatant was transferred to a fresh tube for the reaction with the added 500 $\mu \mathrm{L}$ iso-proanol at room temperature. The RNA was precipitated by centrifugation at $4^{\circ} \mathrm{C}$ and at $12,000 \mathrm{xg}$ for $10 \mathrm{~min}$; the supernatant was removed; the precipitated RNA was diluted and washed by $\mathrm{H}_{2} \mathrm{O}$ treated with diethyl pyrocarbonate (DEPC) and the $75 \%$ and $95 \%$ Ethanol, before the dissolution in DEPC $\mathrm{H}_{2} \mathrm{O}$ for extracting the total RNA. For the quantitative and qualitative analyses of total RNA, a spectrophotometer (Nanovue) was used for the measurements, and the sample exhibiting the purity of 1.7-2.1 for A260/A280 nm ratio was chosen and confirmed via electrophoresis.

For cDNA synthesis, the total RNA extracted from the brain tissue was used as template. Using the RQ1 RNase-Free DNase Kit (Promega, USA), the RNA was treated with DNase, then cDNA was synthesized using the PrimeScript ${ }^{\text {mit }} 1^{\text {st }}$ strand cDNA synthesis Kit (Takara, Japan). The DNase-treated RNA was made to $8.0 \mu \mathrm{L}$ with RNase-free $\mathrm{H}_{2} \mathrm{O}$, and after adding $1.0 \mu \mathrm{L}$ Random 6 mers and $1.0 \mu \mathrm{L}$ dNTP mixture, the reaction was left at $65^{\circ} \mathrm{C}$ for $5 \mathrm{~min}$. To this, $4.0 \mu \mathrm{L} 5 \mathrm{X}$ PrimeCript Buffer; $0.5 \mu \mathrm{L}$ RNase inhibitor; $10 \mu \mathrm{L}$ PrimeCript RTase; $4.5 \mu \mathrm{L}$ RNase free $\mathrm{dH}_{2} \mathrm{O}$, were added and the total volume was made to $20 \mu \mathrm{L}$. The reaction proceeded at $30^{\circ} \mathrm{C}$ for $10 \mathrm{~min}$; at $42^{\circ} \mathrm{C}$ for $60 \mathrm{~min}$; at $95^{\circ} \mathrm{C}$ for 5 min, for enzymatic activation and completion of synthesis.

\section{Expression patterns of the reproduction-related genes (Quan- titative RT-PCR)}

For the primer of reproduction-related genes (Kiss, GnRH, GtHs), the sequences registered at the National Center for Biotechnology Information (NCBI) were used for the design and subsequent use (Table 1). To investigate the expression patterns of reproduction-related genes, Quantitative Real-time (RT-) PCR was used for the quantitative analysis. For this, the BioRad CFX96 ${ }^{\text {mo }}$ Touch ${ }^{\text {ma }}$ Real Time PCR (BioRad, Hercules, CA) and the EvaGreen 2X qPCR MasterMix-RoxKit (abm, Canada) were used. To $2.0 \mu \mathrm{L}$ of cDNA template, 5.0 $\mu \mathrm{L}$ EvaGreen $2 \mathrm{X}$ qPCR MasterMix; $0.3 \mu \mathrm{L}$ forward primers; $0.3 \mu \mathrm{L}$ reverse primers; 2.4 $\mu \mathrm{L}$ RNasefree $\mathrm{H}_{2} \mathrm{O}$, were added and the total volume was made to 10 $\mu \mathrm{L}$. Next, 40 cycles of denaturation $\left(45 \mathrm{~s}, 94^{\circ} \mathrm{C}\right)$, annealing $\left(45 \mathrm{~s}, 58^{\circ} \mathrm{C}\right)$, and extension $\left(1 \mathrm{~m}, 72^{\circ} \mathrm{C}\right)$, were carried out for amplification. The procedure was repeated twice for each sample, and B-actin was used for the relative quantification, from which the average experimental values were obtained and subsequently used.

\begin{tabular}{|c|c|c|c|}
\hline \multirow{2}{*}{ Gene } & \multicolumn{3}{|c|}{ Primer information } \\
\hline & Primer & 5'-3' sequence & Amplicon size (bp) \\
\hline \multirow{2}{*}{ Kiss1 } & Kiss1 F & TGCCACGACTCATTGTTGC & \multirow{2}{*}{225} \\
\hline & Kiss1 R & AGATCCACCATCCTGACCTG & \\
\hline \multirow{2}{*}{ Kiss2 } & Kiss2 F & GGCCTGATTGTTGGACAGGA & \multirow{2}{*}{166} \\
\hline & Kiss2 R & TCTCGCTCAGGGACAAACAC & \\
\hline \multirow{2}{*}{ GPR54 } & GPR54 F & TCTCCCTGGATGGATCTTTG & \multirow{2}{*}{198} \\
\hline & GPR54 R & GAGCCAATCCAAATGCAGAT & \\
\hline \multirow{2}{*}{ sbGnRH } & $\mathrm{sbGnRH} F$ & АCTGTGTCTGCTGCTTGTGG & \multirow{2}{*}{192} \\
\hline & sbGnRHR & TTGGCAAAAGGTGATTCCTC & \\
\hline \multirow{2}{*}{$\mathrm{FSH} \beta$} & $\mathrm{FSH} \beta \mathrm{F}$ & ACGTGAGACCTGCAGACGAT & \multirow{2}{*}{301} \\
\hline & FSH $\beta$ R & AGTTTCTGGCCACAGGGTAG & \\
\hline \multirow{2}{*}{$\mathrm{LH} \beta$} & $\mathrm{LH} \beta \mathrm{F}$ & TACAGGTCGGCAGAGTGATG & \multirow{2}{*}{389} \\
\hline & LH $\beta R$ & CTCGAAGGTGCAGTCAGATG & \\
\hline \multirow{2}{*}{$\beta$-actin } & $\beta$-actin F & GAGCGTGGCTACTCCTTCAC & \multirow{2}{*}{390} \\
\hline & $\beta$-actin R & AGGAAGGAAGGCTGGAAGAG & \\
\hline
\end{tabular}

Table 1: Primer set used for real time quantitative PCR. 

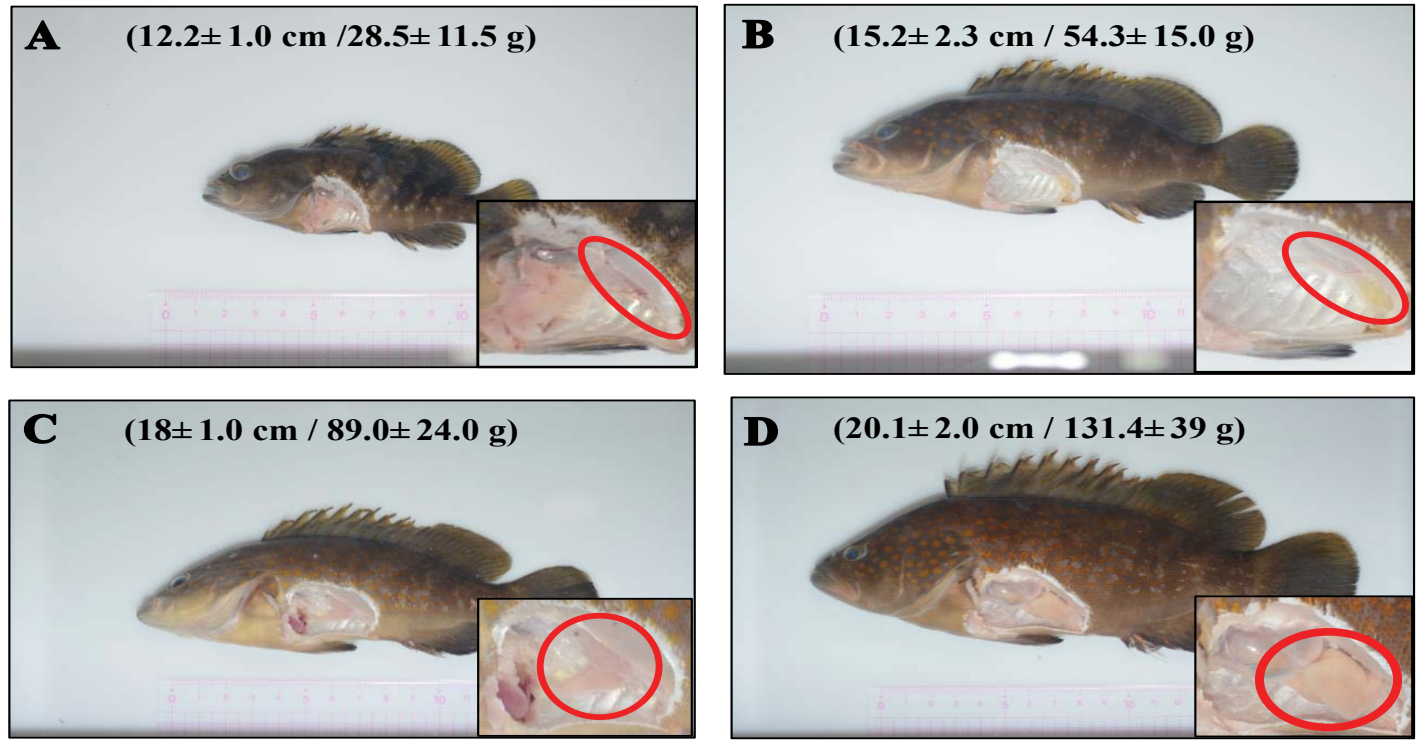

Figure 1: The exterior gonad of red spotted grouper in different rearing water temperatures. (A) The gonad of fish reared natural water temperature condition (NC); (B) The gonad of fish reared $20 \pm 0.5^{\circ} \mathrm{C}$ treatment group; (C) The gonad of fish reared $24 \pm 0.5^{\circ} \mathrm{C}$ treatment group; (D) The gonad of fish reared $28 \pm 0.5^{\circ} \mathrm{C}$ treatment group.

\section{Artificial fertilization}

In August 2015, the 1-year-old red spotted grouper fish whose puberty had been induced under $28 \pm 0.5^{\circ} \mathrm{C}$ condition, were selected. For sperm production and egg ovulation, the abdominal compression method was used, and artificial fertilization was performed through wet process using $24 \pm 0.5^{\circ} \mathrm{C}$ filtered sea water. The rates of fertilization and hatching were estimated under the $24 \pm 0.5^{\circ} \mathrm{C}$ rearing WT condition. The fertilized eggs displayed the characteristics of floating eggs, and the fertilization rate of red spotted grouper was determined by the proportion of the eggs that floated following the artificial fertilization. The hatching occurred after 48 -hour incubation under the $24 \pm 0.5^{\circ} \mathrm{C}$ rearing WT condition, and the hatching rate was determined by placing 500 washed eggs in a $1000 \mathrm{ml}$ beaker and counting the larvae and spawned eggs.

\section{Statistical analysis}

SPSS version 21 was used for statistical analysis, for applying One-Way analysis of variance (ANOVA), and the Duncan's multiple range test (Duncan, 1955) to validate the significance. The values were expressed in mean \pm standard deviation, and the significance of difference was accepted at $P<0.05$.

\section{Result}

\section{Change of growth and gonadosomatic index}

After 8 months of water temperature (WT) manipulation, we have measurement of experimental fish total length (TL) and body weight (BW). At the initiation of an experiment (110 days after hatching), juvenile red spotted grouper TL and BW were no different between control and treatment groups. At the end of the experiment, TL and BW of 1-year-old red spotted grouper in the natural condition were $12.2 \pm 1.0 \mathrm{~cm}$ and $28.5 \pm 11.5 \mathrm{~g}$, respectively. The TL in $20 \pm 0.5^{\circ} \mathrm{C}, 24$ $\pm 0.5^{\circ} \mathrm{C}$ and $28 \pm 0.5^{\circ} \mathrm{C}$ treatment groups were $15.2 \pm 2.3 \mathrm{~cm}, 18 \pm 1$ $\mathrm{cm}$ and $20.1 \pm 2.0 \mathrm{~cm}$, respectively. The BW were $54.3 \pm 15.0 \mathrm{~g}, 89.0 \pm$ $24 \mathrm{~g}$ and $131.4 \pm 39 \mathrm{~g}$, respectively (Table 2 and Figure 1 ). The TL and $\mathrm{BW}$ were tended to increase as the rearing water temperature increased $(\mathrm{P}<0.05)$.

At the end of the experiment, both GSI of 1-year-old red spotted grouper in the natural condition and $20 \pm 0.5^{\circ} \mathrm{C}$ treatment group were $0.003 \pm 0.001$. But GSI of $24 \pm 0.5^{\circ} \mathrm{C}$ and $28 \pm 0.5^{\circ} \mathrm{C}$ treatment groups were $1.34 \pm 0.48$ and $3.04 \pm 1.79$, respectively (Figure 2 ). Their GSI were shown to have developed further compared to the natural condition and $20 \pm 0.5^{\circ} \mathrm{C}$ group.

\section{Gonadal development for each WT treatment groups}

After 8 months of WT manipulation, the gonad development in each WT group was comparatively analyzed through histological analysis. The ovaries of 1 -year-old red spotted grouper from the natural condition and $20 \pm 0.5^{\circ} \mathrm{C}$ treatment group were immature, mainly contained oogonia stage oocytes of 12 to $17 \mu \mathrm{m}$ in diameter and perinucleolus stage oocytes of 30 to $50 \mu \mathrm{m}$ diameter, respectively (Figures $3 \mathrm{~A}$ and $3 \mathrm{~B}$ ). But, in the $24 \pm 0.5^{\circ} \mathrm{C}$ and $28 \pm 0.5^{\circ} \mathrm{C}$ treatment groups, the ovaries become mature as vitellogenic oocytes of 320 to $350 \mu \mathrm{m}$ diameter (Figures 3C and 3D), with $33.3 \%$ and $53.3 \%$ mature individuals in each group (Figure 4).

\section{The mRNA expression patterns of the reproduction-related genes}

To explore the activities of B-P-G axis according to the rearing WT manipulation, mRNA expression patterns of the reproductionrelated genes from whole brain including the pituitary gland were investigated. The expressions of Kisspeptin1, 2 mRNAs did not show significant difference between each WT treatment groups. In the case of Kisspeptin1, relatively higher expression was observed from the 28 $\pm 0.5^{\circ} \mathrm{C}$ treatment group compared to other groups (Figure $5 \mathrm{~A}$ ). In the case of Kisspeptin2, relatively higher expression was observed from 24 
Citation: Oh SB, Lee CH, Lee YD (2018) Induction of Puberty in Red Spotted Grouper, Epinephelus akaara By Water Temperature. J Aquac Res Development 9: 537. doi: 10.4172/2155-9546.1000537

Page 4 of 7

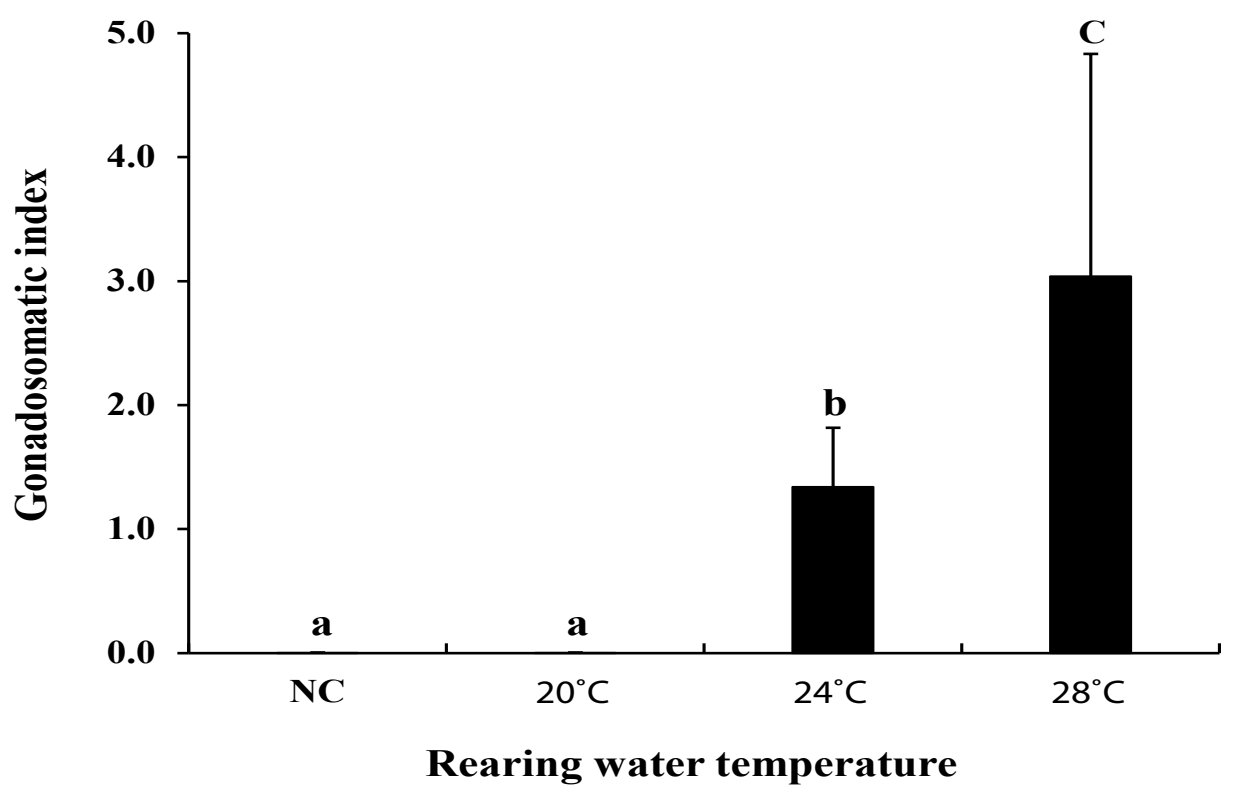

Figure 2: Gonadosomatic index of the female red spotted grouper under each other rearing water temperatures. Means represent by different letters are significant $(p<0.05)$. NC; Natural condition.
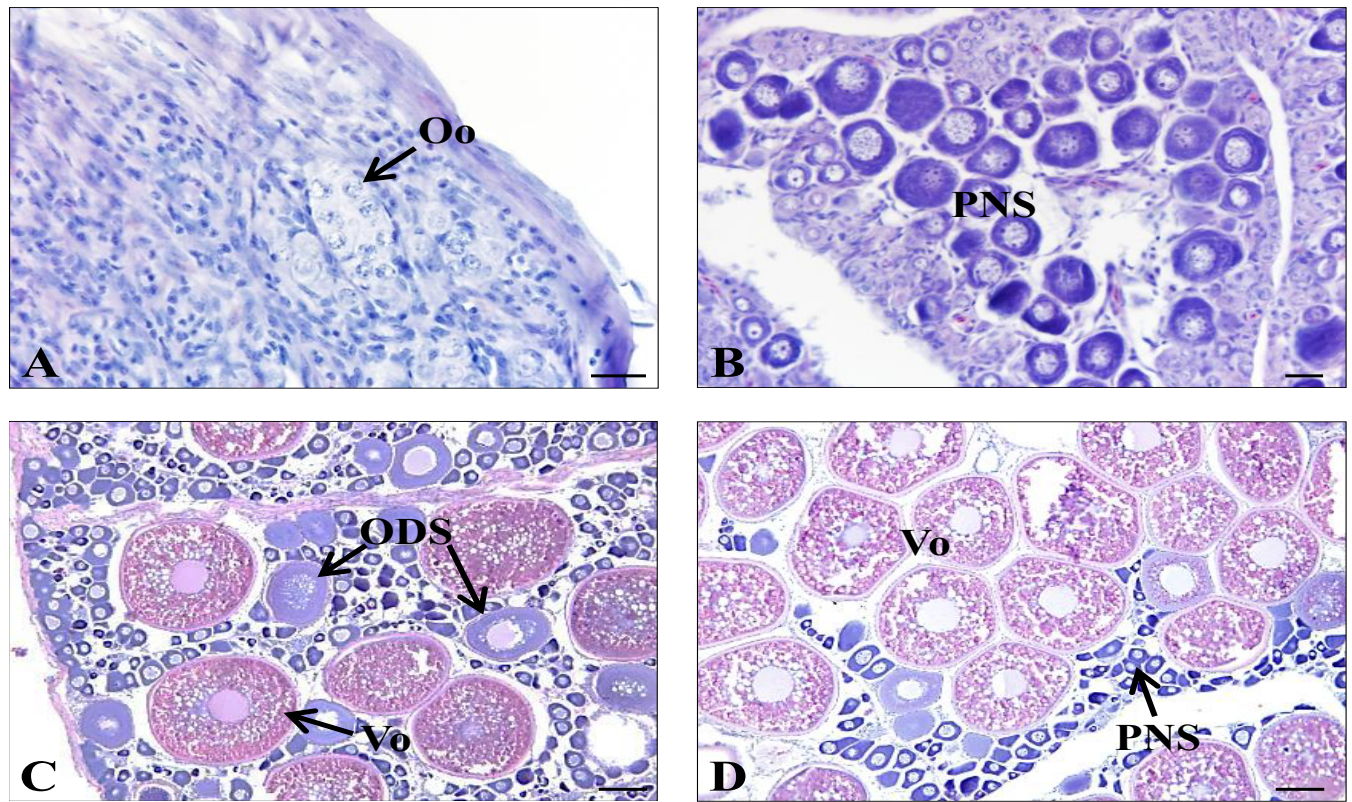

Figure 3: Development of red spotted grouper gonad by histological analysis in different rearing water temperatures $(n=5 ; 5 ; 10 ; 10)$. (A) The fish reared in natural condition; (B) An immature fish reared in $20 \pm 0.5^{\circ} \mathrm{C}$ treatment group; (C) A few mature fish reared in $24 \pm 0.5^{\circ} \mathrm{C}$ treatment group; (D) A mature fish reared in $28 \pm$ $0.5^{\circ} \mathrm{C}$ treatment group. Oo, oogonia; PNS, peri-nucleolus stage; ODS, oil droplet stage; Vo, vitellogenic oocytes. Sscale bars indicate $20 \mu \mathrm{m}$ (A and B) and $100 \mu \mathrm{m}$ (C and D).

$\pm 0.5^{\circ} \mathrm{C}$ and $28 \pm 0.5^{\circ} \mathrm{C}$ treatment group than the other groups (Figure $5 \mathrm{~B}$ ). The expression of Gpr54 (kiss1r) mRNA was the highest in the $28 \pm 0.5^{\circ} \mathrm{C}$ treatment group, showing a similar trend to Kisspeptin 1 mRNA expression (Figure 5C). The expression of $\mathrm{GnRH}$ (seabream type) mRNA did not show significant difference between the natural condition and the $20 \pm 0.5^{\circ} \mathrm{C}$ treatment group, but expressions in the $24 \pm 0.5^{\circ} \mathrm{C}$ and $28 \pm 0.5^{\circ} \mathrm{C}$ groups were significantly higher than the natural condition (Figure 5D, $\mathrm{P}<0.05)$. The expression of $\mathrm{GtHs}(\mathrm{FSH} \beta$, $\mathrm{LH} \beta)$ mRNA was higher in the $24 \pm 0.5^{\circ} \mathrm{C}$ and $28 \pm 0.5^{\circ} \mathrm{C}$ treatment group than the other groups (Figures $5 \mathrm{E}$ and $5 \mathrm{~F}, \mathrm{P}<0.05$ ).

\section{Fertilized egg production of 1-year-old red spotted grouper fish in puberty}

In August 2015, a male $(19.7 \pm 1.8 \mathrm{~cm} \mathrm{TL}, 110.8 \pm 40.4 \mathrm{~g} \mathrm{BW})$ and a female $(18.6 \pm 0.3 \mathrm{~cm} \mathrm{TL}, 131.0 \pm 40.2 \mathrm{~g} \mathrm{BW})$ red spotted grouper reared in $28 \pm 0.5^{\circ} \mathrm{C}$ group until they became a year old, were selected. Using the abdominal compression method, their sperms and eggs were collected. The amount of eggs was $6-13 \mathrm{ml}$, which corresponded to 
Citation: Oh SB, Lee CH, Lee YD (2018) Induction of Puberty in Red Spotted Grouper, Epinephelus akaara By Water Temperature. J Aquac Res Development 9: 537. doi: 10.4172/2155-9546.1000537

Page 5 of 7

\begin{tabular}{|c|c|c|c|c|}
\hline \multirow{2}{*}{$\begin{array}{c}\text { Experimental } \\
\text { group }\end{array}$} & Total length (cm) & Body weight (g) & Total length (cm) & Body weight (g) \\
\hline N.C. & $7.5 \pm 0.7^{\mathrm{a}}$ & $6.80 \pm 1.6^{\mathrm{a}}$ & $12.2 \pm 1.0^{\mathrm{a}}$ & $28.5 \pm 11.5^{\mathrm{a}}$ \\
\hline $20 \pm 0.5^{\circ} \mathrm{C}$ & $7.1 \pm 0.6^{\mathrm{a}}$ & $6.05 \pm 1.5^{\mathrm{a}}$ & $15.2 \pm 2.3^{\mathrm{b}}$ & $54.3 \pm 15.0^{\mathrm{b}}$ \\
\hline $24 \pm 0.5^{\circ} \mathrm{C}$ & $7.2 \pm 0.6^{\mathrm{a}}$ & $6.42 \pm 1.6^{\mathrm{a}}$ & $18.1 \pm 1.0^{\mathrm{c}}$ & $89.0 \pm 24.0^{\mathrm{c}}$ \\
\hline $28 \pm 0.5^{\circ} \mathrm{C}$ & $7.2 \pm 0.5^{\mathrm{a}}$ & $6.16 \pm 1.1^{\mathrm{a}}$ & $20.1 \pm 2.0^{\mathrm{d}}$ & $131.4 \pm 39.0^{\mathrm{d}}$ \\
\hline \multicolumn{2}{|l}{} & N. C.: Natural condition & & \\
\hline
\end{tabular}

Table 2: Change of red spotted grouper growth in different rearing water temperature.

\begin{tabular}{|c|c|c|c|c|c|}
\hline $\begin{array}{c}\text { Number } \\
\text { of fish }\end{array}$ & $\begin{array}{c}\text { Total } \\
\text { length } \mathbf{( c m})\end{array}$ & $\begin{array}{c}\text { Body } \\
\text { weight } \mathbf{( g )}\end{array}$ & $\begin{array}{c}\text { Ovulated } \\
\text { egg (mL) }\end{array}$ & $\begin{array}{c}\text { Floated } \\
\text { egg (mL) }\end{array}$ & $\begin{array}{c}\text { Fertilization } \\
\text { rate } \mathbf{( \% )}\end{array}$ \\
\hline 13 & $18.6 \pm 0.3$ & $131.0 \pm 40.2$ & $11.8 \pm 3.5$ & $11.2 \pm 3.3$ \\
\hline
\end{tabular}

Table 3: Induced ovulation and fertilization of 1-year-old red spotted grouper.

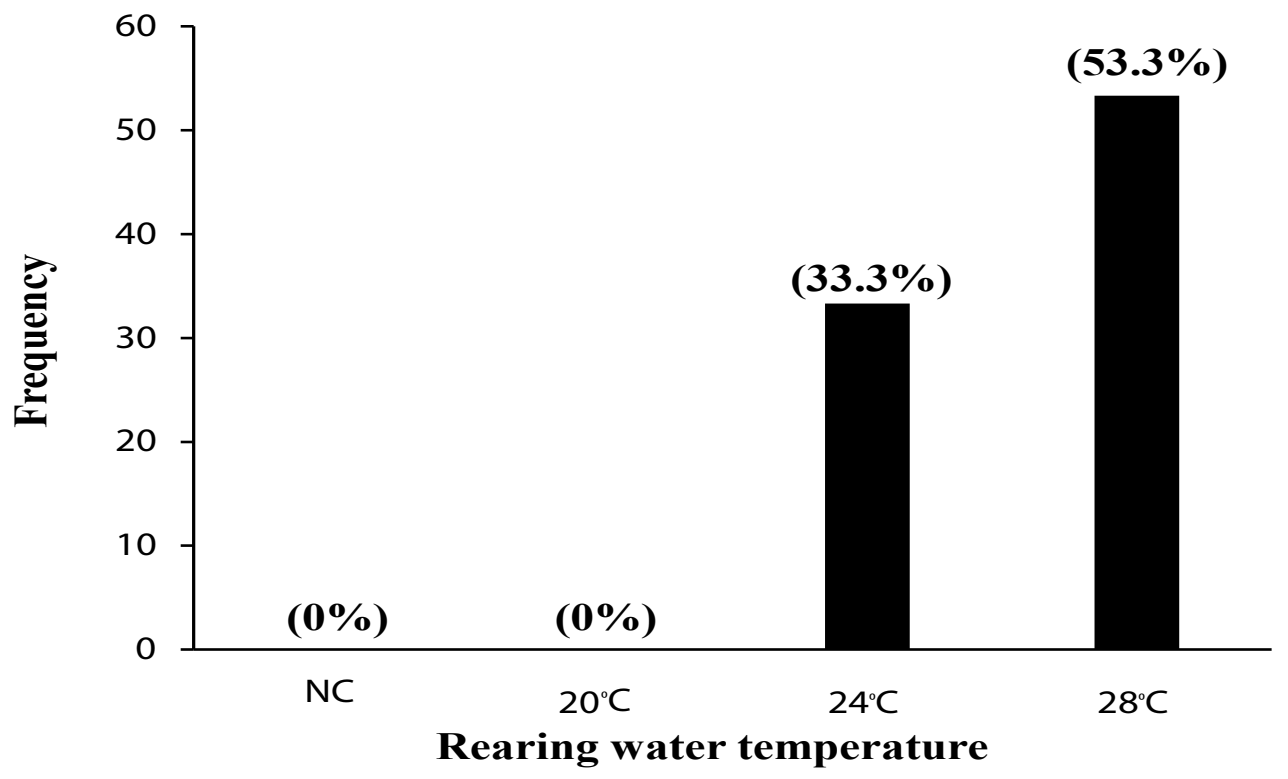

Figure 4: Matured fish rate under each other rearing water temperatures by histological analysis $(n=10 ; 10 ; 15 ; 15)$. NC: Natural condition.

approx. $10 \%$ of the body weight of fish. For the artificial fertilization, the fertilization rate was $95 \%$ and the hatching rate was $97 \%$ (Table 3).

\section{Discussion}

The puberty of fish has been shown to bear correlation with age, growth, and the activities of B-P-G axis which is the reproductive endocrine axis. The activities of B-P-G axis are in turn affected by light, WT, weight, and feed [3]. The puberty of sea bass and Nile tilapia could be induced through the increased expressions of the reproduction-related genes by photoperiod control [2,21], and the puberty of pikeperch could be induced under the conditions of natural photoperiod and $14^{\circ} \mathrm{C}$ rearing WT [22]. The puberty of longtooth grouper and dusky grouper were shown to be correlated with weight $[12,23]$, and that of various other farmed fish were shown to be correlated with factors such as age and growth [3]. As such, puberty in fish is induced when the reproductive endocrine axis of fish receives the signals from environmental and physiological factors, which initiates the expressions of the reproduction-related genes (Kiss, Gpr54, GnRH, $\mathrm{GtH}$ ) and the maturation of gonad.
Among the reproduction-related genes of fish, Kisspeptin and Gpr54 are known to play a crucial role in puberty $[21,24]$. Increased Gpr54 expression was observed at the onset of puberty in Nile tilapia [21], and mammals (rat, mouse, sheep) were also shown to induce GnRH secretion through Kisspeptine expression at the onset of puberty [25]. GnRH induced the GtHs secretion and it was influenced by the increase in Gpr54 expression [26,27], while the GnRH mRNA production increased with the onset of puberty $[21,28]$. Several different types of GnRH exist, and the gonad development in sea basses or basses are often influenced by the sea bream type GnRH expression $[29,30]$. GtHs is another key factor in puberty [1,2]. In Chinook salmon fish, the expressions of FSH $\beta$ and LH $\beta$ increased during puberty [31], while in African catfish and European sea bass, the level of LH $\beta$ expression also increased during puberty [29,32]. The present study, likewise, where the puberty of red spotted grouper was induced, showed a gradually increasing trend in the mRNA expressions of Kiss1, 2 with the increase in rearing WT, although no significant between-group differences were found. Also, the mRNA expressions of Gpr54, GnRH (sb), and GtHs, were relatively high in high WT groups than in low WT groups with statistical significance. When the gonad development 

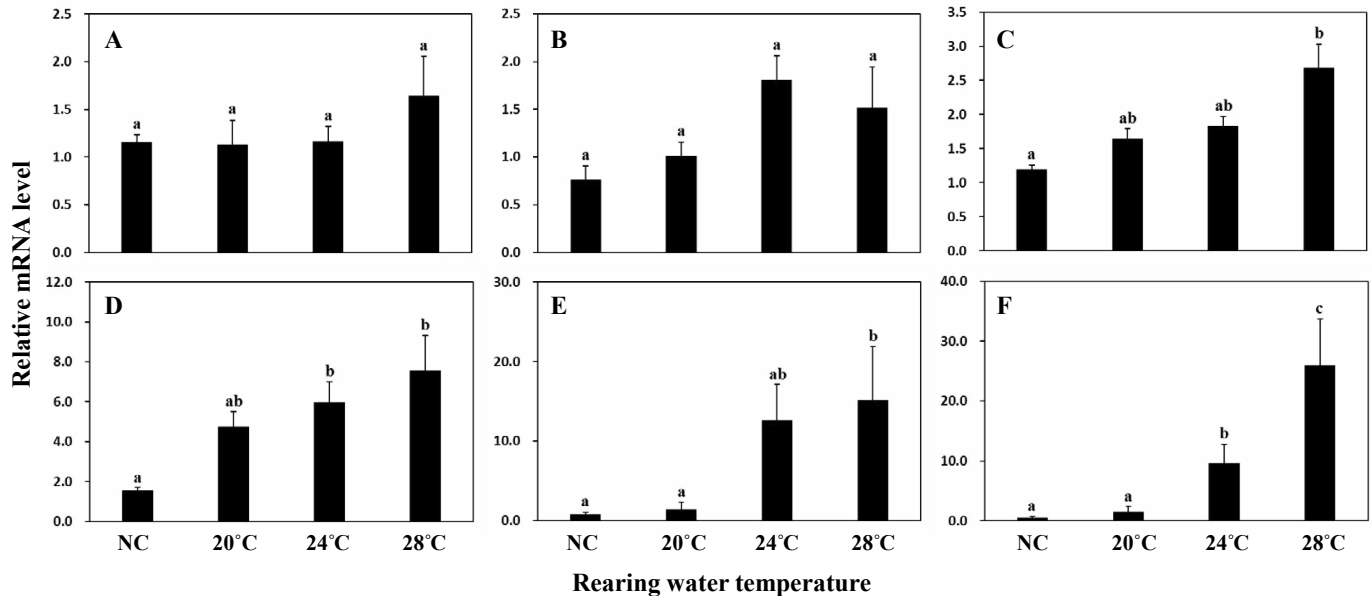

Figure 5: Expression of reproduction-related genes in brain (with pituitary) by real-time PCR ( $\mathrm{n}=5 ; 5 ; 10 ; 10)$. (A) Kisspepitn1 mRNA; (B) Kisspeptin2 mRNA; (C) G protein-coupled receptor 54 mRNA; (D) GnRH (seabream type) mRNA; (E) FSH $\beta$ mRNA; (F) LH $\beta$ mRNA each other rearing water temperatures. The results are represented as means \pm SEM and different letters are significant $(p<0.05)$. NC, Natural condition.

of red spotted grouper was observed through histological analysis, the gonad was not shown to have developed in the natural condition and $20 \pm 0.5^{\circ} \mathrm{C}$ groups, whereas in the $24 \pm 0.5^{\circ} \mathrm{C}$ and $28 \pm 0.5^{\circ} \mathrm{C}$ treatment groups, mature individuals were observed mostly with mature oocytes. Growth hormone (GH) induces the synthesis of Igf1, 2 in the liver [33]. In rainbow trout, WT affects promote growth through Igf1 secretion by the liver following GH stimulation [34], in Atlantic salmon, these hormones were shown to be associated with growth and maturation [35].

Igf1 of Japanese eel and tilapia is known to stimulate the gonad of fish and induce the secretion of 11-Ketotestosterone to influence sperm production [36,37]. Igfs expression was also found in gilthead seabream and during the early mature yolk stage of tilapia $[38,39]$, while in goldfish, it was shown to regulate yolk formation [40]. Although the expressions of growth-related genes Igfs and $\mathrm{GH}$ were not investigated in this study, faster growth was exhibited by $24 \pm 0.5^{\circ} \mathrm{C}$ and $28 \pm 0.5^{\circ} \mathrm{C}$ WT groups compared to natural condition and $20 \pm 0.5^{\circ} \mathrm{C}$ WT groups.

In fish, the onset of puberty begins with the activity of B-P-G axis. Water temperature and photoperiod are very important environmental factor and it can modulate the activity of B-P-G axis. The manipulation of water temperature can be used to advance or prevent the onset of puberty in some fish. For example, in the initiation puberty of pikeperch, the most efficient effect is observed at $12^{\circ} \mathrm{C}$, while high $\left(23^{\circ} \mathrm{C}\right)$ or low $\left(6^{\circ} \mathrm{C}\right)$ temperature prevented gonadal maturation [41].

\section{Conclusion}

In this study, the puberty of subtropical red spotted grouper may have been induced by direct and indirect influences of water temperature, with close correlation to the rearing WT. The water temperature induces changes of activity of the B-P-G axis and is considered as the most important environmental cue determining the timing of puberty in red spotted grouper. With recent reports on the receptors sensitive to light and WT, metabolism, physiology and behavior of diverse fish including zebrafish and rainbow trout [42-44] the mechanism correlating the WT-sensitive receptor and B-P-G axis should be investigated in future.

\section{Acknowledgement}

This research was supported by Golden Seed Project, Ministry of Agriculture, Food and Rural Affairs(MAFRA), Ministry of Oceans and Fisheries(MOF), Rural Development Administration(RDA) and Korea Forest Service(KFS).

\section{References}

1. Schulz RW, Miura T (2002) Spermatogenesis and its endocrine regulation. Fish Physiol Biochem 26: 43-56.

2. Carrillo M, Zanuy S, Felip A, Bayarri MJ, Molés G, et al. (2009) Hormonal and environmental control of puberty in perciform fish. Ann N Y Acad Sci 1163: 49-59.

3. Taranger GL, Carrillo M, W.Schulz R, Fontaine P, Zanuy S, et al. (2010) Control of puberty in farmed fish. Gen Comp Endocrinol 165: 483-515.

4. Schulz RW, Goos HJT (1999) Puberty in male fish: Concepts and recent developments with special reference to the African catfish (Clarias gariepinus). Aquaculture 177: 5-12.

5. Okuzawa K (2002) Puberty in teleosts. Fish Physiol Biochem 26: 31-41.

6. Yoneda M, Wright PJ (2005) Effects of varying temperature and food availability on growth and reproduction in first $\square$ time spawning female Atlantic cod. J Fish Biol 67: 1225-1241.

7. Oliveira C, Mañanós E, Ramos J, Sánchez-Vázquez FJ (2011) Impact of photoperiod manipulation on day/night changes in melatonin, sex steroids and vitellogenin plasma levels and spawning rhythms in Senegal sole, Solea senegalensis. Comp Biochem Physiol Part A: Mol Integr Physiol 159: 291-295.

8. Giannecchini LG, Massago H, Fernandes JBK (2012) Effects of photoperiod on reproduction of Siamese fighting fish Betta splendens. R Bras Zootec 41: 821-826.

9. Brown NP, Shields RJ, Bromage NR (2006) The influence of water temperature on spawning patterns and egg quality in the Atlantic halibut (Hippoglossus hippoglossus L.). Aquaculture 261: 993-1002.

10. Glasser F, Mikolajczyk T, Jalabert B, Baroiller JF, Breton B (2004) Temperature effects along the reproductive axis during spawning induction of grass carp (Ctenopharyngodon idella). Gen Comp Endocrinol 136: 171-179.

11. Gen K, Okuzawa K, Senthilkumaran B, Tanaka H, Moriyama S, et al. (2000) Unique expression of gonadotropin-I and -II subunit genes in male and female red seabream (Pagrus major) during sexual maturation. Biol Reprod 63: 308-319.

12. Ryu YW, Hu SW, Hur SP, Lee CH, Lim BS, et al. (2013) Characterization of pubertal development phases in female longtooth grouper, Epinephelus bruneus via classification of bodyweight. Dev Reprod 17: 55-62.

13. Ohga H, Adachi $\mathrm{H}$, Matsumori $\mathrm{K}$, Kodama R, Nyuji M, et al. (2015) mRNA levels of kisspeptins, kisspeptin receptors, and $\mathrm{GnRH} 1$ in the brain of chub mackerel during puberty. Comp Biochem Physiol Part A. Mol Integr Physiol 179: 104-112.

14. Kang HC, Lee CH, Song YB, Baek HJ, Kim HB, et al. (2012) KISS1, KISS2, GPR54 mRNA expression of the blacktip grouper Epinephelus fasciatus. Dev 
Citation: Oh SB, Lee CH, Lee YD (2018) Induction of Puberty in Red Spotted Grouper, Epinephelus akaara By Water Temperature. J Aquac Res Development 9: 537. doi: 10.4172/2155-9546.1000537

Reprod 16: 121-128.

15. Kayano Y, Oda T (1994) Growth and spawning of red spotted grouper, Epinephelus akaara, under artificial rearing condition. Suisan Zoshoku 42: 419-425.

16. Li GL, Liu XC, Lin HR (2006) Effects of aromatizable and nonaromatizable androgens on the sex inversion of red-spotted grouper (Epinephelus akaara). Fish Physiol Biochem 32: 25-33.

17. Li GL, Liu XC, Lin HR (2007) Seasonal changes of serum sex steroids concentration and aromatase activity of gonad and brain in red-spotted grouper (Epinephelus akaara). Anim Reprod Sci 99: 156-166.

18. Huang W, Zhou L, Li Z, Gui JF (2009) Expression pattern, cellular localization and promoter activity analysis of ovarian aromatase (Cyp19a1a) in protogynous hermaphrodite red-spotted grouper. Mol Cell Endocrinol 307: 224-236.

19. Annalie VM, Roberts CM, Hawkins JP (2000) The threatened status of groupers (Epinephelinae). Biodivers Conserve 9: 919-942.

20. Baillie J, Taylor CH, Stuart SN (2004) The 2004 IUCN red list of threatened species. IUCN, Glands, Switzerland.

21. Martinez-Chavez CC, Minghetti M, Migaud H (2008) GPR54 and rGnRH I gene expression during the onset of puberty in Nile tilapia. Gen Comp Endocrinol 156: 224-233.

22. Hermelink B, Wuertz S, Rennert B, Kloas W, Schulz C (2013) Temperature control of pikeperch (Sander lucioperca) maturation in recirculating aquaculture systems-induction of puberty and course of gametogenesis. Aquaculture 400: 36-45.

23. Andrade ÁB, Machado LF, Hostim-Silva M, Barreiros JP (2003) Reproductive biology of the dusky grouper Epinephelus marginatus (Lowe, 1834). Braz Arch Biol Technol 46: 373-382.

24. Navarro VM, Castellano JM (2007) Neuroendocrine factors in the initiation of puberty: The emergent role of kisspeptin. Rev Endocr Disord 8: 11-20.

25. Messager S, Chatzidaki EE, Ma D, Hendrick AG, Zahn D, et al. (2005) Kisspeptin directly stimulates gonadotropin-releasing hormone release via $G$ protein-coupled receptor 54. Proc Natl Acad Sci USA 102: 1761-1766.

26. Mohamed JS, Benninghoff AD, Holt GJ, Khan IA (2007) Developmental expression of the $\mathrm{G}$ protein-coupled receptor 54 and three GnRH mRNAs in the teleost fish cobia. J Mol Endocrinol 38: 235-244.

27. Filby AL, Van Aerle R, Duitman J, Tyler CR (2008) The kisspeptin/gonadotropinreleasing hormone pathway and molecular signaling of puberty in fish. Biol Reprod 78: 278-289.

28. Ojeda SR, Lomniczi A, Mastronardi C, Heger S, Roth C, et al. (2006) Minireview: The neuroendocrine regulation of puberty: Is the time ripe for a systems biology approach? Endocrinol 147: 1166-1174.

29. Rodriguez L, Carrillo M, Sorbera LA, Soubrier MA, Mañanós E, et al. (2000) Pituitary levels of three forms of $\mathrm{GnRH}$ in the male European sea bass
(Dicentrarchus labrax, L.) during sex differentiation and first spawning season. Gen Comp Endocrinol 120: 67-74.

30. Holland $\mathrm{MCH}$, Hassin S, Zohar Y (2001) Seasonal fluctuations in pituitary levels of the three forms of gonadotropinreleasing hormone in striped bass, Morone saxatilis (Teleostei), during juvenile and pubertal development. J Endocrinol 169: 527-538.

31. Shearer KD, Swanson $P$ (2000) The effect of whole body lipid on early sexual maturation of $1+$ age male chinook salmon (Oncorhynchus tshawytscha). Aquaculture 190: 343-367.

32. Schulz RW, Zandbergen MA, Peute J, Bogerd J, Van Dijk W Goos HJ (1997) Pituitary gonadotrophs are strongly activated at the beginning of spermatogenesis in African catfish, Clarias gariepinus. Biol Reprod 57: 139-147.

33. Reinecke M (2010) Insulin-like growth factors and fish reproduction. Biol Reprod 82: 656-661.

34. Gabillard JC, Weil C, Rescan PY, Navarro I, Gutiérrez J, et al. (2003) Effects of environmental temperature on IGF1, IGF2, and IGF type I receptor expression in rainbow trout (Oncorhynchus mykiss). Gen Comp Endocrinol 133: 233-242.

35. Björnsson BT, Taranger GL, Hansen T, Stefansson SO, Haux C (1994) The interrelation between photoperiod, growth hormone, and sexual maturation of adult Atlantic salmon (Salmo salar). Gen Comp Endocrinol 93: 70-81.

36. Nader MR, Miura T, Ando N, Miura C, Yamauchi K (1999) Recombinant human insulin-like growth factor I stimulates all stages of 11-ketotestosteroneinduced spermatogenesis in the Japanese eel, Anguilla japonica, in vitro. Biol Reprod 61: 944-947.

37. Tokalov SV, Gutzeit $\mathrm{HO}$ (2005) Spermatogenesis in testis primary cell cultures of the tilapia (Oreochromis niloticus). Dev Dyn 233: 1238-1247.

38. Schmid AC, Näf E, Kloas W, Reinecke M (1999) Insulin-like growth factor-I and-II in the ovary of a bony fish, Oreochromis mossambicus, the tilapia: In situ hybridisation, immunohistochemical localisation, Northern blot and cDNA sequences. Mol Cell Endocrinol 156: 141-149.

39. Perrot V, Moiseeva EB, Gozes Y, Chan SJ, Funkenstein B (2000) Insulinlike growth factor receptors and their ligands in gonads of a hermaphroditic species, the gilthead seabream (Sparus aurata): Expression and cellular localization. Biol Reprod 63: 229-241.

40. Srivastava RK, Van Der Kraak G (1994) Regulation of DNA synthesis in goldfish vitellogenic ovarian follicles by hormones and growth factors. J Exp Zool 270: 263-272

41. Hermelink B, Wuertz S, Trubiroha A, Rennert B, Kloas W, et al. (2011) Influence of temperature on puberty and maturation of pikeperch, Sander lucioperca. Gen Comp Endocrinol 172: 282-292.

42. Kastenhuber E, Gesemann M, Mickoleit M, Neuhauss SC (2013) Phylogenetic analysis and expression of zebrafish transient receptor potential melastatin family genes. Dev Dyn 242: 1236-1249.

43. Nisembaum LG, Besseau L, Paulin CH, Charpantier A, Martin P, et al. (2015) In the heat of the night: Thermo-TRPV channels in the salmonid pineal photoreceptors and modulation of melatonin secretion. Endocrinol 156: 4629-4638.

44. Gracheva EO, Bagriantsev SN (2015) Evolutionary adaptation to thermosensation. Curr Opin Neurobiol 34: 67-73. 